\title{
Theorising Illegal Rural Enterprise: Is everyone at it?
}

\author{
Gerard McElwee \\ Professor of Entrepreneurship \\ Nottingham Business School \\ Nottingham Trent University \\ Burton Street \\ Nottingham, England \\ NC1 4BU \\ Rob Smith \\ Reader in Entrepreneurship \\ Aberdeen Business School \\ The Robert Gordon University \\ Garthdee Road \\ Aberdeen, Scotland \\ AB10 7QE \\ Professor Peter Somerville, \\ University of Lincoln \\ Lincoln, England \\ LN6 4RT
}

Contact author - Gerard McElwee: gerard.mcelwee@ntu.ac.uk; +44 (0) 1158483834

\begin{abstract}
Illegal entrepreneurship in the rural is under researched and scrutinised, yet it occupies a distinctive space in entrepreneurship practice in terms of how it is construed and how it is enacted. This is a theoretical paper which provides a conceptual framework for defining 'ideal types' of illegal rural enterprise activity in order to better frame the phenomenon. Four types of enterprise activity are provided which suggest how the activities of illegal entrepreneurship in the rural can be categorised. This article is valuable to researchers and policy makers in that the framework suggests diversity in illegal rural enterprises which can manifest differing motives and modes of operation.

Keywords: Illegal Rural Entrepreneurs; Opportunity Entrepreneurs; Rural Economy, Value Adding/Value Extracting Entrepreneurship
\end{abstract}




\section{Introduction}

The purpose of this article is to consider the nature of illegal rural enterprise; to establish if it is a distinctive space in entrepreneurship theory and practice; how it is construed; how and if, it is enacted. A conceptual categorisation which links the activities of illegal entrepreneurship in the rural is developed.

The paper will do three things. First it will define what is meant by illegal entrepreneurship in the rural and comment on the bifurcation of entrepreneurs as 'valueadding' or 'value-extracting' and the extent to which the activity of these entrepreneurs can become categorised - if at all. Illegal entrepreneurs, exhibit characteristics, for example, strategic awareness, opportunity spotting and networking, usually associated with more traditional notions of entrepreneurship. One of the problems with researching illegal rural entrepreneurship is that, rural enterprise, as Smith (2004), in his study of the illegal 'smokies' trade in Scotland, suggests, covers such a wider gamut of activities. Secondly, a commentary on the research approach will offered. Third, a theoretical set of types are provided which categorise illegal enterprises. This categorisation is derived from the primary research and the literature. The final section provides some conclusions about the relevance and insights that can be drawn by suggesting that dichotomizing 'value adding' and 'value extracting' entrepreneurship as a mechanism for understanding the challenges and constraints faced by entrepreneurs who operate at the margins of legality is not sufficient - suggesting that all forms of illegal enterprise 'add value' to a greater or lesser extent.

We do not attempt to raise or answer questions of moral space, (Anderson and Smith 2007) or raise questions concerning the 'parasitical nature' of the entrepreneur (Baumol 1995 ) or ethical considerations of enterprise, but merely to begin to consider a theoretical perspective on illegal rural enterprise. Some commentators such Baumol (1995), deplore the debilitating effects that such actors may have on the 'natural' workings of the economy. Thus, ethical issues are not consciously discussed although we recognise that the subject matter is suffused with such issues.

What is clear is that illegal enterprise activities are widespread (Bauchus 1994). In the UK for instance it is estimated that relatively common manifestation for example is illegal trading. Fadahunsi and Rosa (2002) suggest that this exists in three forms: 1) the trading of goods or services that are normally forbidden by law for example, narcotic drugs, prostitution, certain categories of arms, rare wildlife; 2) the avoidance of payment of taxes or duties on the trading of legal goods and services; 3) using illegal unfair practices to attain a competitive advantage for insider trading, organizing clandestine cartels and monopolies, tax evasion, black market currency exchange. 
It may be suggested that another form may be proposed i.e. the alternative use of existing spaces, places and resources: faces, places and spaces. The faces are the entrepreneurs and their peer based communities, the places are farms, businesses, the agricultural mart and the pub and the spaces are the entrepreneurial opportunities to be exploited.

\section{The Research Question}

The recurring research question is simple, "What is the nature of the illegal rural enterprise and can it be conceptualised?" Entrepreneurship is widely regarded as a driver of economic development and growth (Harper 2003). Williams (2008) argues that there appears to be a clear distinction between 'necessity-driven' entrepreneurs pushed into entrepreneurship because other options for work are mostly absent or unsatisfactory, and 'opportunity-driven' entrepreneurs who engage in entrepreneurship out of choice. In this paper, we consider a different bifurcation of illegal entrepreneurs: 'value-adding' and 'value extracting' and ask whether it is a useful or indeed appropriate distinction. A simple framework is provided which is intended to stimulate discussion and further research. The framework is informed by the literature review and informal conversations held with actors within the industry: police and rural entrepreneurs.

\section{Conceptualising the Illegal Rural Entrepreneur}

The first task is to define what is meant by the terms 'entrepreneurship' 'rural enterprise' 'illegal entrepreneurship' and 'value adding' and 'value extracting'. For the purposes of this paper illegal entrepreneurship is defined as the process whereby entrepreneurs supply willing customers with illegal services or products or legal services or products using an illegal process. These customers may not necessarily be fully aware of the illegal nature of the transaction of the service or product which they are acquiring or the legality of the process of which they are part.

At first examination the distinction between rural and urban enterprises may appear arbitrary. It is the nature of the endogenous and exogenous factors which influence the potential strategic capability and activity of the enterprise. The internal factors are personal characteristics - qualities and skills of the entrepreneur. External factors, many of which are outside of the control of the individual entrepreneur, include the activities and processes undertaken by the entrepreneur, the characteristics of the enterprise itself, policies, markets and environmental factors.

One starting point for a paper on illegal rural entrepreneurship is to theorise that there is little difference between a rural and non-rural enterprise other than the extent to which the start up, development of and support for is constrained by endogenous factors such as geographical location, access to labour markets, infrastructure and value chains for 
example (McElwee 2006). Yet these factors may be significant. The very constraints facing some businesses can be opportunities for others, for example, Bosworth (2008) argues that some rural areas are growing because of in-migration or counter-urbanisation. The decline in traditional industries such as farming and mining has led to new economic activity which has moved into rural areas which are consequently characterised by a mix of employment sectors which mirror that of England as a whole, and higher rates of selfemployment (Countryside Agency 2001).

The types of enterprises found in rural areas are very similar to the types of businesses found in urban areas (Roberts 2002), however, enterprises in rural areas tend to be smaller than their urban counterparts (CEEDR 2002; Lowe and Talbot 2000). For example the Countryside Agency (1999) indicated that $91.4 \%$ of all VAT registered enterprises have fewer than 10 employees. North and Smallbone (2000a, 2000b) work with rural firms found that relatively few felt constrained by their rural location.

\section{Methodology}

Although a theoretical paper which provides a conceptual framework for defining types of illegal rural enterprise activity, a method which has been termed 'Empirically Based Theorising' (Down 2006) is utilised. This is an amalgam of personal and collective knowledge based around a subject. Knowledge has been extrapolated from industry insiders, in particular rural police and rural entrepreneurs. Consequently, the research approach is exploratory and of a qualitative nature underpinned by a phenomenological framework.

\section{Phenomenology}

The term phenomenology can be used to describe a research perspective which as an alternative to positivistic forms of enquiry (Burrell and Morgan 1979, Bogdan and Taylor 1975). The term is used here to denote the form of enquiry which we have attempted to use to understand the illegal activities of rural entrepreneurs. Following Weber, this indicates an interest in the tradition of interpretative understanding or verstehen related to the life worlds of the entrepreneur, their culture and their ways of being in and looking at the world. This is what phenomenology asks the researcher to do - not to take received notions for granted. Thus, the aim is to attempt to understand the 'subjective' experience of the entrepreneur by listening to the ways in which they make sense of the world and ascribe and attribute value to their experiences. As Bogdan and Taylor (1975: 14) so succinctly frame it:

"the task of the qualitative methodologist... is to grasp the meanings of a person's behavior, the phenomenologist attempts to see things from that person's point of view." 
Little research using ethnomethodological, phenomenological, social constructionism and other interpretative approaches in the rural entrepreneurship literature exists. Recently, however, such interpretative approaches have been used in entrepreneurship research. For example, Rae (2000) and Rae and Carswell (2000) use interpretative methods. Cope (2003) uses the phenomenological interview, and Devins and Gold (2002) use social constructionism to understand the 'life worlds' of managers in SMEs. McElwee and Atherton (2005) demonstrate the predominance of the objectivist approaches in the entrepreneurship literature developing the work of Grant and Perrin (2002) who argue that new perspectives on entrepreneurship can only be achieved when the debate moves out of the 'paradigmatic cage' of positivism. Translating and understanding the interpretive accounts of illegal rural entrepreneurs about their experiences, is of course a complex process for as Denzin and Lincoln (2000: 14) indicate:

"individuals are seldom able to give full explanations of their actions or intentions all they can offer are accounts, or stories, about what they did and why. No single method can grasp the subtle variations in ongoing human experiences."

As Cope (2003: 12) suggests, phenomenological approaches are “..inherently inductive rather than deductive, where theoretical propositions emerge from the descriptions of experience given by individuals under investigation."

Thus the philosophical and practical methodological approach is influenced by Weber's interpretative sociology, phenomenology and social constructionism and the contribution these approaches make to a social, rather than a purely economic understanding of the illegal entrepreneur.

\section{The Process}

Getting data implies "[getting] inside situations by empirically generating qualitative data through interaction with a number of key respondents", as Burrell and Morgan suggest (1979: 7). Actually identifying key respondents is a bit more complex. The interviewees are selected (chosen) using various formal criteria: age, gender, geography, size of business etc. Informal criteria are also used: commonsense, gut reaction and value judgment. We look for people who are able to reflect about their activities.

The meeting with respondents usually occurs at a location of their choosing, the farmhouse, a pub, a barn, a farm office, and then an interview process is orchestrated. We talk and attempt to stick to an agenda. Stories are received from respondents who 
know their opinions are of interest - as otherwise the respondents would not be interviewed. Sometimes, but not always, the interviews are taped. In this instance we have talked to farmers and owner/managers of rural businesses, rural police, trading standards officers and others. The interviews and conversations were with respondents in the North East of England and Scotland in 2007 and 2008.

\section{Findings}

\section{Characteristics and Structure}

What is apparent is that rural enterprises are usually isolated from other enterprises and do not have the same networking opportunities and business support as their urban counterparts - factors which are critical for business growth. All of which would suggest that the characteristics and structure of illegal rural enterprise and the illegal rural entrepreneur should be no different to the characteristics of the illegal urban entrepreneur. All that is different is the type of enterprise will differ. However, one of the respondents suggested that:

"in reality this is far from the case. The rural criminal has a very different profile from the urban one. They are likely to have their first conviction in early adulthood as opposed to in their teenage years. They will accrue fewer convictions and these will be less analogous than their urban counterparts. Many will be for breaches of the peace or more mundane convictions. Farmers may well have cruelty (to animals) or other job related convictions".

Thus what is legal or illegal is dependent on the nature of the law not on the nature of the enterprise. For example, similar enterprises could be illegal under certain jurisdictions and legal in others. As Durkheim (1965) might have said, however, a function of law is to provide a system of rules that can encourage or discourage entrepreneurial activity. For example, it has commonly been argued that a free economy requires a strong state in the sense of a legal and political enabler of free enterprise. So what is evident is that different sorts of laws either encourage or discourage entrepreneurial activity. With specific reference to rural enterprise it is evident that some entrepreneurs in some circumstances operate outside the law.

Clearly, illegal entrepreneurship can be located within what Williams (2006) refers to as the informal economy but, and as will be seen, there is a blur between what is considered to be legal by the entrepreneurs themselves and the apparent willingness for individuals to break the law when the opportunity presents itself and when there is little likelihood of being caught. Indeed, this paper suggests that defining and understanding 
illegal entrepreneurship is improved by being broadened to encompass all forms of illegal entrepreneurship, irrespective of specific contexts. Moreover, illegal entrepreneurship may not be always informal.

Despite the rhetoric and official theoretical position on entrepreneurship acting as a generator of employment and economic prosperity, there are some forms of entrepreneurial activity which consciously and pragmatically seek to avoid any form of official recognition, by governments or governmental agencies, which may expose them to public scrutiny. These are those entrepreneurial activities which Smith (2007) has so succinctly labelled illegal entrepreneurship, which operates at the margins of legal entrepreneurship, termed here illegal entrepreneurial activities. This contested marginal area is however illusory because it occurs in the mainstream but is paradoxically hidden from public view by the privacy afforded by the rural location and the ownership or stewardship of land.

There appears to be no consensus regarding the specific causes, functions, and entrepreneurial potential of illegal economic activity per se, but there is agreement (Smith 2004; Wempe 2005; Fadanhunsi and Rosa 2002) on characteristics of the illegal sector:

- It is not a purely a marginal activity of marginal entrepreneurs.

- It is connected to the formal, modern, capitalist economy.

- Those who work within the illegal economy may receive less benefits and protections than labour in the formal sector.

- It is available to any who have the entrepreneurial capability and choose to engage in it.

- Some elements of the illegal entrepreneurship may benefit from a government attitude of tolerance.

- Illegal enterprise is an entrepreneurial process similar to legal entrepreneurial process.

- Many product or service can be part of the illegal economy.

- It normally, but not always, operates in cash or in kind.

- It can be a pluriactive illegal venture.

\section{What Entrepreneurs Do}

The recognition of business opportunities and strategic planning are major requirements for entrepreneurs. Through this, entrepreneurs are able to find ways and strategies to create a profitable business. Cooperation and networking skills, innovative abilities and risk taking are important requirements to realise business opportunities. 
Business monitoring and reflection, team working and leadership are prerequisite skills necessary to develop and improve the enterprise.

This analysis is generally in line with literature on entrepreneurship (McElwee 2005). Other descriptions of entrepreneurship emphasise opportunity recognition and realisation (Stevenson and Jarillo 1990; Timmons 1999; Scott and Venkataraman 2000), the acceptance of risk and failure, innovation and the creation of something new (Kuratko and Hodgetts, 1998; Hisrich and Peters 1998), the role of networks and cooperation (Kuratko and Hodgetts 1998) and strategic thinking (Dana 2004).

Entrepreneurship is widely recognised as a vital driver of economic development and growth (Harper 2003) but the contribution of illegal entrepreneurship to rural economic development is less known. There is however a cultural (and romanticized) tradition of illegality in the countryside: in Scotland for example smuggling and illegal distilling form part of the mythology.

The promotion of entrepreneurship is based on the premise that those individuals who are successful in their endeavours will improve not only their own economic well-being but that of others too. Entrepreneurship, from this perspective is understood and presented as both a private and a public good. However, Buckley and Casson (2001: 314) caution that entrepreneurship is neither driven by nor necessarily results in improvements in economic welfare for all:

"To maximise their profit, entrepreneurs may drive hard bargains with their customers and suppliers. They do not tell their customers the prices for which they purchased the goods they are reselling, and they do not tell their suppliers the price at which they can re-sell. They are allowed to bluff...Bluffing is not considered lying, although the effect is much the same: with successful bluffing, the buyer pays more than he needs to, and the seller receives less than he could get."

Buckley and Casson (2001) argue that entrepreneurship is, and has always been, a morally ambiguous pursuit, suggesting that entrepreneurship, always entails a degree of exploitation. As such, there is a very explicit moral dimension inasmuch as whether or not the moral code of an individual actor finds such trading conditions and consequences acceptable. Indeed, there are many people who turn away from entrepreneurship and business more generally as they are unable to feel comfortable engaging in such activities. There is, therefore, a moral dimension to entrepreneurship that warrants further attention within the entrepreneurship literature.

There are difficulties associated with defining the entrepreneur; indeed, as noted by Palich and Bagby (1995:426), "when tracing the development of this concept in the 
literature, it becomes clear that no one definition of the entrepreneur prevails". Definitions have emphasised a broad range of activities, the more well-known of which include uncertainty-bearing and the subcontractor who takes risks (Cantillon 1755), coordination (Say 1803), innovation (Schumpeter 1942) and arbitrage (Kirzner 1979).

Where enterprise and entrepreneurship is explored in a rural context, studies have tended to focus on the dynamics and behaviours of individuals, often focusing on farmers as entrepreneurs within a rural setting (e.g., Carter 1996; Kalantaridis and Bika 2006; McElwee 2006a; McElwee 2006b). Carter and Rosa (1998), McNally (2001) argue that the methods used to analyse business entrepreneurs in other sectors can be applied to rural businesses. However, the characteristics of the classical theory of the firm, i.e., capital raised by share ownership, separation of ownership and management control, and profit maximisation, do not readily apply themselves to the illegal enterprise if at all. The relationship between the illegal entrepreneur and the enterprise (which may be legal or not) is in itself a complex issue, as the entrepreneur can be an owner, a tenant, a manager, a subcontractor or a combination of these, suggesting that the methods used to analyse business entrepreneurs in other sectors may not be easily transferred to an analysis of the illegal enterprise.

The problem of definition is not confined to entrepreneurship for there also are issues of conceptualisation when terms such as 'illegal' or moral are used. Furthermore, it may be suggested that to understand the phenomenon necessitates understanding the attitudes and motivation of the entrepreneur in an environmental and personal context.

Drawing on earlier work with drug dealers (Frith and McElwee 2008) and considering research into illegal entrepreneurship it is suggested that illegal rural entrepreneurs may well have multiple business interests which generate employment creation and rural economic development.

This is a key issue. Standard definitions of entrepreneurs ignore both the multiple interests, the social entrepreneurial role of and manifestations of the illegal enterprise. At present there is there is still a paucity of knowledge about which factors trigger the startup of entrepreneurial activities of illegal entrepreneurs.

Are illegal entrepreneurs in the rural different to legitimate entrepreneurs in the rural or indeed illegal entrepreneurs in urban environments? Are they equipped with certain entrepreneurial and management skills and therefore capable of managing environmental uncertainty? What motivates them? 


\section{The Research Problematic}

McElwee (2006b) has demonstrated that there is a great deal of literature on entrepreneurship and a commensurate level of literature on the related field of rural enterprise and illegal business. However, there is very little written which combines these three topics.

For Schramm 'the temptation to set aside ethical standards is always present because the gains are so large for the individual who decides to work outside the rules' (2006: 279). Schramm makes it very clear that entrepreneurs are socially embedded individuals but have two distinct and often competing obligations - obligations to themselves and obligations to the society within which they and others work and live. On certain occasions these obligations align or coincide, thus benefiting a wider community, on others they do not. To quote Wempe (2005: 215)

"There is the view that ethics (together with the law) limits entrepreneurship. Ethics (and laws) formulates standards that give entrepreneurship some space. Ethics and entrepreneurship are seen as two entirely separate areas. Entrepreneurship is viewed as amoral, or perhaps even as immoral. Entrepreneurs need to exploit opportunities and consider all options. This should occur within the boundaries set by the law, and complemented by ethics."

Wempe infers that entrepreneurs, in the first instance, seek to satisfy their own selfinterest and that wider considerations, informed by ethics and laws, are secondary. As such, according to Wempe (2005: 215), in order to be effective, laws and ethics have to be at least as developed as the self-interest that they have emerged to counter or constrain:

“...legislation and ethics limit the scope within which an entrepreneur can move. It is thanks to such free enterprise that welfare and prosperity are served in the best possible way. Legislation and moral precepts are there to ensure that this does not occur at the expense of the weak within the market."

Baumol's (1990) discussion of productive, unproductive and destructive entrepreneurship is relevant here and important in positioning an argument for a valueextracting/value-adding dichotomy as a clear heuristic. Value-adding and valueextracting entrepreneurial behaviours have been used as labels to understand the moral dimensions of entrepreneurship. Value-adding entrepreneurship creates value in excess of that which accrues to the entrepreneurial individual and, as such, includes benefits which accrue to society more broadly. Value-adding entrepreneurship occurs within and 
valorises prevailing legislative and ethical guidelines. Value-extracting entrepreneurship, on the other hand, involves activities that enrich the individual but which impoverish the society within which they occur. Value-extracting entrepreneurship occurs outside of and seeks to delegitimize established legislative structures and ethical mores. This distinction has emerged comparatively recently within the entrepreneurship literature but is nonetheless important in that it challenges the prevailing assumption that entrepreneurship is always a good thing. As such, there is a need to further our understanding of how entrepreneurs shape and are shaped by their own moral guidelines and the social expectations or ethical frameworks within which they operate (Bucar et al 2003).

The promotion of enterprise and entrepreneurship has tended to focus on business start up in the formal sector and, as a consequence, has paid little attention to the nature and types of illegal entrepreneurship, although Frith and McElwee (2009) Smith and Christou (2009) Williams (2009) Smith (2008) document enterprise activity that occurs at 'the margins.' Research into illegal entrepreneurship has sought to explore why certain groups and individuals, despite not fitting the conventional description of the entrepreneur, have managed to engage in enterprise and entrepreneurship.

As an academic discipline, entrepreneurship has always been concerned with understanding how entrepreneurs work at and beyond the boundaries of what is known and, occasionally, of what is accepted in the pursuit of profits. However, the majority of research exploring illegal entrepreneurship has tended to focus on the marginalized entrepreneur rather than on illegal entrepreneurship per se. This apercus is primarily based on a reading of the entrepreneurship literature and not of the literatures of the sociology of organised crime white collar criminality and the emerging literature on rural crime, Cases of entrepreneurship involving minority entrepreneurs (Galloway, 2007), illegal enterprises (Rehn and Taalas 2004; Smith, 2004; 2007; Williams 2008, 2009), drug dealers (Frith and McElwee 2007; 2009) and other such marginal activities (Storr and Butkevich, 2007) have been the most common instantiation of this type of research to date. The individuals involved in these enterprises have been commonly portrayed as deviant and often as social outcasts who operate at the margins of society. This type of research has, by and large, documented cases of entrepreneurship that mainstream, and hence more widely accepted entrepreneurship research has tended to ignore.

Many of the activities described by Fadahunsi and Rosa in the introduction are usually attributed to larger corporations located in urban environments: these are easier organisations for sociologists to gain access to. What is less apparent and thus not reflected in the literature is the illegal activities of SMEs and micro enterprises in rural settings. 
Nevertheless, as Galloway (2007: 271) suggests, research exploring illegal entrepreneurship has helped to challenge 'current stereotype-based knowledge' and draw attention to the heterogeneity or diversity of entrepreneurial activities and individuals which, according to Schindutte et al (2005: 27-28), has furthered the "development of...theory regarding the larger population."

We now turn to another important, though frequently overlooked dualism within the entrepreneurship literature, that of value-adding and value-extracting entrepreneurship.

\section{'Value Adding' and 'Value Extracting' Entrepreneurship in the Rural}

Illegal entrepreneurs [appear] to operate at the margins because the margins are not clearly defined, are perceived differently and because, as a result, profits can be achieved. Whereas the majority of entrepreneurship studies are concerned with exploring and explaining how entrepreneurs improve the allocative efficiency of economies, Etzioni (1987: 175) suggests that the activities of entrepreneurs help to change obsolescent and ossified societal patterns.

A relevant example might be when an individual anticipates a change in the ethical environment and so creates a new business venture that underlines and benefits from this change, such as a producing free range eggs (or capitalising on the free range market by falsely attributing free range status to eggs from battery farming). Although the exploitation of such opportunities does not depend on the entrepreneurial individual having a consonant moral outlook (they may simply be attempting to 'cash in' on new possibilities), such opportunities are more likely to be identified by individuals whose viewpoints are aligned with and reflect the changing environment. In addition, entrepreneurs are more likely to identify opportunities in which they have a particular and, as is often the case, vested interest. Entrepreneurs, in such instance, are at the forefront of societal change and do much to expedite periods of transition.

There are, however, entrepreneurs whose activities slow or even retard the development of social welfare by engaging in activities that are do not benefit the wider community. In such instances, there is a clear rupture between individual and social perspectives such that the moral viewpoints of the entrepreneurial individual are exposed as being misaligned with prevalent ethical parameters. These individuals perpetuate and compound this fundamental tension between individual moral standpoints and use the space thereby created to exploit opportunities that other individuals, with differing moral opinions, would find objectionable.

For Kirzner, a substantial proportion of entrepreneurial activity does not enrich or expand the totality of human knowledge but, nevertheless, helps to improve market efficiency and overall economic welfare (Kirzner 1973). Entrepreneurs who are engaged 
in activities of arbitrage, for example, are considered as value-adding entrepreneurs as they work to ensure that resources are put to their most productive or profitable use. Value-adding entrepreneurship can therefore be defined as those types of entrepreneurial activities which are legitimate but which do little to change or effect the margins within which they operate. Value-extracting entrepreneurship can be defined as those types of entrepreneurial activity that occur within existing margins but which impoverish or damage the community within which they occur. Illegal enterprises, including drugdealing and fencing (selling 'hot' or stolen goods), for example, are perhaps the most common form of this type of activity and tend to follow or mimic very closely legitimate forms of entrepreneurship. Indeed, removing or ignoring the moral or ethical issues associated with such activities renders them almost imperceptible from traditional forms of entrepreneurship.

Smith (2007: 245) argues that illegal entrepreneurship should move away from mainstream or typical cases of entrepreneurship and instead focus on cases of entrepreneurship that are at the 'edge of the known and accepted' as there are 'many areas of entrepreneurship that exist at the boundaries of our knowledge and that are worthy of further study'. Although this definition focuses attention upon illegal entrepreneurship as opposed to entrepreneurship on the margins, it makes it clear that there is an aspect of entrepreneurship (levels of acceptance) that is very important to the growth and survival of such endeavours. As argued above, there are entrepreneurs working within the margins of what is known and accepted, however, there are also entrepreneurs whose activities help to influence and shape the margins themselves. As such, we take the view that research into illegal entrepreneurship should be concerned with all types of entrepreneurial activities in which the margins themselves are in the process of being challenged, reconsidered, redefined, and, in certain circumstances, redrawn altogether. As a consequence, the entrepreneur has been most commonly presented as a lone individual, a maverick hero whose skills and expertise in opportunity spotting are singular concerned with profit maximisation (Nodoushani, and Nodoushani 2000).

However, depictions of the entrepreneur as a dispassionate and efficient calculator of economic costs and benefits neglects that fact that entrepreneurs are socially active individuals whose actions and behaviours alter, both positively and negatively, the environment within which they and others both work and live. Furthermore, such characterisations do not resonate with real-world accounts and experiences in which entrepreneurs are often seen to be at the forefront of social change.

For Etzioni (1987: 175) "Entrepreneurs, by promoting new patterns, help bring society and its component units in touch with reality." Etzioni's argument is questionable. Entrepreneurs are not disembedded from societal patterns but exist in and 
through such patterns: institutions can and do shape the environment as well as vice versa. Although a great deal of entrepreneurship research does not explore the ethical consequences of entrepreneurial activities, it is clear that many entrepreneurial initiatives do much to influence and shape the behaviours and ethics of the communities within which they occur.

\section{The Conceptual Framework}

The recurring question in the paper is, "What is an illegal entrepreneur in the context of the rural economy?" This section develops a conceptual framework of the illegal rural entrepreneur. The premise underpinning the framework is that the spatial dimensions of illegal rural entrepreneurs (IREs), in relation to their economic activity, are variable, rather than uniform, and should not be considered and represented as a homogeneous and single-faceted phenomenon. The different forms and types of IREs highlight their intrinsic heterogeneity.

The rural business sector is shaped by many different forces, which include factors or drivers that influence local economic development - such as geography; topography and physical location; access to transport and distribution networks; proximity to markets; size and skill of labour force. Other qualitative factors, including culture and social networks and capital, also influence entrepreneurial activity.

The review of the literature discussed in the above sections allows the development of a conceptual list of types which attempt to characterise the illegal rural entrepreneur. This typology aims to synthesise the preceding discussion of the IRE into a single means of representing its many dimensions and particularities and to make sense of the concepts of the IRE.

\section{Classifying the Illegal Rural Enterprise}

Four types of rural enterprise are suggested. All of the entrepreneurs who run these types of enterprise 'meet' or coalesce and network in a central market place - 'The Market'. They do this either formally or informally and either virtually or physically. In the Market, information and ideas are exchanged, deals are brokered and in some cases plots hatched. Two dimensional tables are problematic. Clearly, there is crossover between each of the 'types'. Table 1 below depicts the four types. 
Table 1: A Framework of Illegal Rural Enterprises

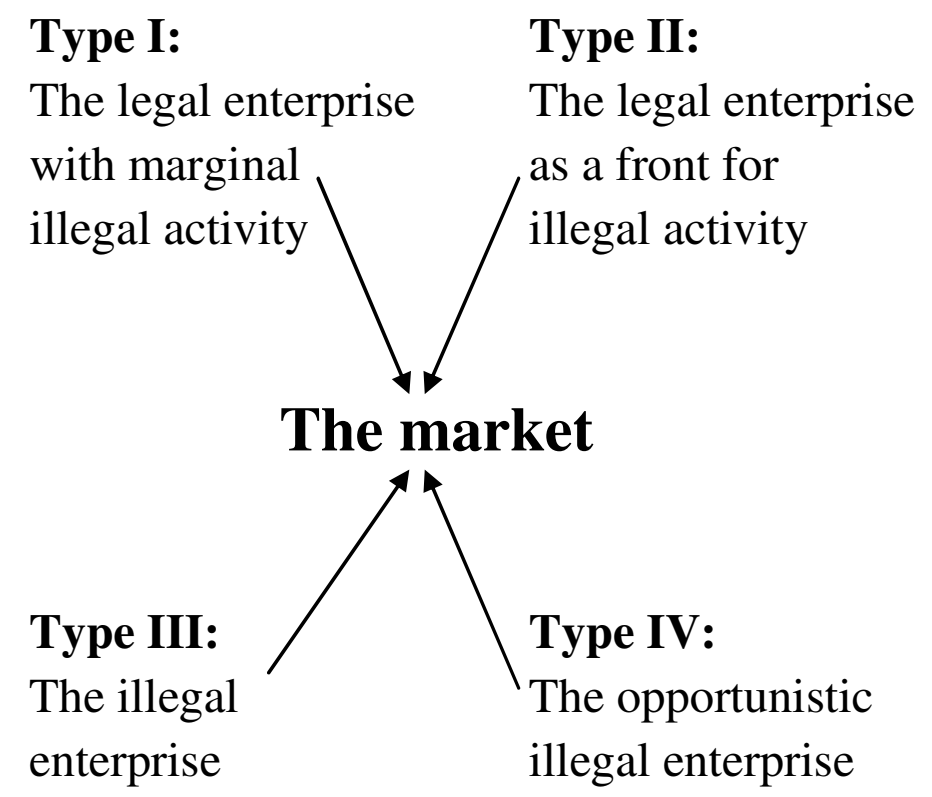

\section{Type I: The Legal Enterprise with Marginal Illegal Activity}

This enterprise is formally registered as a business but will engage in semi-legal activities when possible. The entrepreneur may not perceive these activities as particularly problematic. Such activities may include the alternative use of expertise and equipment, for example agricultural fitters or mechanics may use the legal business premises for an off the books business venture servicing cars or agricultural vehicles on a strictly cash basis. Alternatively it may involve accepting cash for allowing others access to the premises or equipment. This may even occur inadvertently when a farmer enters into an arrangement with a silent partner who abuses the trust of the individual. Even 'Gentlemen Farmers' are not immune from acting illegally or on the borders of morality as evidenced by the following examples - the abuse of political or fraternal contacts to gain pecuniary or reputational advantage. In extreme cases this could include bribery to win a contract. Many such farmers are local councillors or politicians and can use contacts to their advantage.

This category of illegal entrepreneurship could include the illegal sale of livestock or meat from livestock without registering the animal. Another example is farmers who engage in EU subsidy frauds. One police interviewee suggested "What must be remembered is that such individuals all operate from a position of social advantage and 
that the businessman-farmer status conferred upon them allows them freedom to operate from police surveillance." The deliberate commission of environmental crimes such as polluting the environment with slurry spillages can also be legitimately placed in this category because operational pressure in factory farming scenarios can cause farmers to take risks and cut corners. Likewise many ostensibly honest farmers still run the risk of running vehicles illegally on red diesel. The illegal use of labour and gangmaster crime is another linkage. Many such individuals have a 'storied' and almost legendary status in farming circles for their sharp practice.

\section{Type II: The Legal Enterprise as a Front for Illegal Activity}

This could pertain to a rural entrepreneur allowing his or her business to be used for money laundering purposes with criminal knowledge / intent. One such anecdotal example relates to a drug dealer from an urban environment buying a country garage business and running it down whilst using it as a vehicle for laundering money on fictitious deals. Alternatively it could relate to a haulier operating an unviable business to gain a more lucrative income stream from drug running or from off the books haulage of illegal substances. In these examples the entrepreneur's main activities are 'hidden' by the core business.

\section{Type III: The Illegal Enterprise}

This enterprise is likely to be structurally efficient. It will have access to supply networks and clear knowledge of its customers and markets. Examples of such enterprises may include: drug dealing, smuggling, prostitution and poaching. In a rural context the relationship between the rural entrepreneur and in particular the farming community will be tenuous or symbiotic. Often the farmer will have sold or rented surplus accommodation to a tenant. There is a market for such rural retreats amongst the criminal fraternity. A group of criminals or an individual will rent or acquire the property to evade police attention. They use the property either for cannabis factories or for a drugs stash. Hyder (1999) referred to this typology as the 'Greenbelt Bandit'. Hyder's bandits were organized criminal gangs in the Home counties but the analogy holds across the U.K. Often the farmer will be unaware that his tenants are acting illegally but this is not always the case because there is a lucrative market in the rental of property on a 'no questions asked 'which is being exploited by Chinese organized Crime gangs. Often these roving bandits exploit the vulnerability of the rural community to crime. Other examples include illegal 'puppy farming' and 'halal slaughter' (Smith 2008). The fact of the matter is that once such a modus vivendi is in place between such bandits and rogue farmers it may lead to the commission of other illegal activities. This can manifest itself as illegal smuggling of alcohol, cigarettes and contraband goods or even wildlife crime. There is a hidden nexus where the urban criminal underworld meets the rural underworld 
and this can manifest itself in the form of illegal dog fighting, hen fighting, illegal dog racing and badger baiting, hare coursing and in the commercial poaching of deer and salmon. The first four scenarios can entail the illegal use of spaces and places. They usually occur in isolated rural locations and involve gambling - huge sums of money can change hands.

\section{Type IV: The Opportunist Illegal Enterprise}

This type of enterprising activity is loosely configured. The person who engages in the activity is likely to be presented with an opportunity that cannot be missed. The activity may require an enterprising skill set. An example is cattle rustling and sheep stealing which requires specialist insider knowledge to commit. Other examples include farmers exploiting the foot and mouth outbreak to capitalise on the halal market to make money on sheep which had lost their market value. Another example is the trade in illegal veterinary products or farmers renting out barns for illegal raves or to illegal shooting parties. All of the above crimes / entrepreneurial opportunities do not occur in isolation as they require the active participation of an illegal entrepreneur from the rogue farming community (Smith 2004).

\section{Conclusions}

The central discussion on which this paper is based, that is, the similarities in approaches to entrepreneurship in two very different contexts, has policy implications. There has been an assumption in both the literature and rural crime policy that entrepreneurs are engaged primarily in value-adding activities and that value-extracting forms of entrepreneurship can be eradicated from the economic landscape by increasing the level of punishments and chances of detection (European Commission 1998; Renooy et al. 2004). However, if governments adopt such an approach, they may well deter the types of entrepreneurship and enterprise that through enterprise policies they are seeking to nurture. Recognizing the integrative and dynamic nature of entrepreneurial behaviours is, therefore, more than simply a matter of academic interest. A fuller and more nuanced understanding of value-extracting entrepreneurs' motives and behaviours is crucial so that appropriate public policy decisions can be taken towards this hidden enterprise culture, such as initiatives to enable these entrepreneurs to legitimise their business ventures rather than solely measures to eradicate these enterprises. If this paper therefore stimulates further studies that evaluate whether there is the same co-presence of opportunity factors and dynamism in entrepreneurs' motives elsewhere, as well as greater reflection on what should be done about the prevalence of value-extracting entrepreneurs, then the paper will have fulfilled its objectives. 
Illegal Rural entrepreneurship (IRE) is a difficult concept to qualify and/or quantify, and hence to boundary. Because the sector is heterogeneous it is not possible to characterise IREs as a class and hence determine their properties - for example, being entrepreneurial. The taxonomy described in this paper helps us understand the role of the IRE. It suggests that some IREs have more entrepreneurial skills than others.

In the introduction it was indicated that the paper is not necessarily concerned with the morality of illegal entrepreneurship. Nevertheless from both a policy and a social perspective illegal entrepreneurship it cannot be ignored. For Fadahunsi and Rosa (2002: 397): "Illegality discourages honest entrepreneurs, bribes add to the costs of trading, undermine revenues to the State that would otherwise have percolated back in the form of infrastructural improvements and business support." Whether or not this is a full picture of illegal activity in the rural needs to be seen. It may be the case that a reason for IRE is that those who engage in it would disagree that 'honest' enterprise provides the social and economic benefits alluded to by Fadahunsi and Rosa (2002).

A potential typology has been provided to illustrate the linkages between illegal entrepreneurship and business in the rural economy. Further work is necessary to develop theory. What is clear furthermore is the difficulty of obtaining data because of access to such enterprises and entrepreneurs. Strong qualitative research is necessary in order to exploit this area of research and to understand the phenomenon.

It is not clear whether 'illegal enterprise' represents a distinct social form however and consequently further empirical research is now necessary to test the theoretical possibilities of the framework described in the paper. The intention is to provide case material to populate the framework and to determine if it is a 'good' representation. Furthermore, the value adding/value extracting dichotomy and its applicability to the illegal rural enterprise needs further examination.

Ethics appears to be crucial to the argument about the difference between legal and illegal entrepreneurship. So the discussion on this needs to be far more explicit, e.g. what is meant by 'value'? The concept of social capital is useful for such an analysis. It might be argued that all enterprises illegal or not add value in some form or another. There are some enterprises whose externalised costs may well exceed the value added by their activities, so in that sense they could be described as 'value-extracting'.

Further questions can be posed about the architects of the margins - of the law, ethics and morality. This is not the entrepreneur as she or he only chips away at the margins. If we use Durkheimian theory, crime (here described as illegal enterprise) is a constant in human societies. Important differences are found, however, in how and when illegality is defined and acted upon in differing structural and cultural circumstances. 


\section{References}

Anderson, A. \& Smith, R. 2007. The moral space in entrepreneurship: Ethical imperatives and moral legitimacy. Aberdeen Business School Working papers 1(1)

Atherton, A. 2004. Unbundling enterprise and entrepreneurship: From perceptions and preoccupations to concept and practice. International Journal of Entrepreneurship and Innovation, 5, 121-127.

Baucus, M.S. 1994. Pressure, opportunity and predisposition: a multivariate model of corporate illegality. Journal of Management, 20, 699-721.

Baumol, W.J. (1995). Economic Theory and Operations Analysis. Upper Saddle River, New Jersey: Prentice-Hall.

Baumol, W. 1990. Entrepreneurship: Productive, unproductive and destructive. Journal of Political Economy, 98, 893-921.

Bogdan, R. \& Taylor, S. J. 1975. Introduction to Qualitative Research Methods: A Phenomenological Approach to the Social Sciences. New York: Wiley and Sons.

Bosworth, G. 2008. Entrepreneurial in-migrants and economic development in rural England. International Journal of Entrepreneurship and Small Business, 6, 355-369.

Bouchard, M. \& Dion, C. 2009. Growers and facilitators: probing the role of entrepreneurs in the development of the cannabis cultivation industry. The Journal of Small Business and Entrepreneurship, 22, 28-35.

Bucar, B. Glas, M. \& Hisrich, D. 2003. Ethics and entrepreneurs: An international comparative study. Journal of Business Venturing,18, 261-281.

Buckley, P. \& Casson, M. 2001. The moral basis of global capitalism: Beyond the eclectic theory. International Journal of the Economics of Business, 8, 303-327.

Burrell, G. \& Morgan, G. 1979. Sociological Paradigms and Organisational Analysis London: Heinemann.

Cantillon, R. 1755. Essai sur la Nature du Commerce en General. http://socserv.socsci.mcmaster.ca/ econ/ugcm/3113/cantillon/essay1.txt (accessed on 06/04/2004).

Carter, S. 1996. The indigenous rural enterprise: characteristics and change in the British farm sector. Entrepreneurship and Regional Development 8, 345-358. 
Carter, S \& Rosa, P. 1998. Indigenous rural firms: farm enterprises in the UK. International Small Business Journal 16, 15-27.

CEEDR 2002, Encouraging and Supporting Enterprise in Rural Areas, Report to the Small Business Service, Centre for Enterprise and Economic Development Research, Middlesex University Business School.

Cope, J. P. 2003. Researching entrepreneurship through phenomenological inquiry: philosophical and methodological issues. Working paper LUMSWP2003b/052, Lancaster University, Lancaster.

Countryside Agency. 2001. The State of the Countryside 2001. Countryside Agency, London.

Dana, L.P. 2004. Handbook of Research on International Entrepreneurship. London: Edward Elgar.

Denzin, N.K. \& Lincoln, Y. S. 2000 (2nd ed). Introduction: the discipline and practice of qualitative research. Pp. 1-28 in Denzin, N.K. and Lincoln, Y.S. (eds.) Handbook of qualitative research. Thousand Oaks, California: Sage.

Devins, D. \& Gold, J. 2002. Social constructionism: a theoretical framework to underpin support for the development of managers in SMEs? Journal of Small Business and Enterprise Development 9, 111-119.

Down, S. 2006. Narratives of Enterprise. London: Edward Elgar.

Durkheim, E. 1965. The Rules of the Sociological Method. New York: The Free Press.

Etzioni, A. 1987. Entrepreneurship, adaptation and legitimization. Journal of Economic Behaviour and Organization, 8, 175-189.

Fadahunsi, A. \& Rosa, P. 2002 Entrepreneurship and illegality: Insights from the Nigerian cross-border trade. Journal of Business Venturing, 17, 397-429.

Frith, K. \& McElwee, G. 2009. Value adding and value extracting entrepreneurship at the margins. The Journal of Small Business and Entrepreneurship, 22, 39-54.

Frith, K. \& McElwee, G. 2009. The entrepreneurial wide boy. A modern morality tale. International Journal of Entrepreneurship and Small Business, 5, 16-26.

Frith, K. \& McElwee, G. 2008. An emergent entrepreneur? A story of a drug-dealer in a restricted entrepreneurial environment. Society and Business Review, 3, 270-286. 
International Journal of Rural Criminology, Volume 1, Issue 1(December), 2011

Galloway, L. 2007. Entrepreneurship and the gay minority: Why the silence? International Journal of Entrepreneurship and Innovation 8(4), 271-280.

Grant, P \& Perren, L. 2002. Small business and entrepreneurial research. International Small Business Journal 20, 185-211.

Hannafey, F. 2003. Entrepreneurship and ethics: A literature review. Journal of Business Ethics, 46, 99-110.

Harper, D. 2003. Foundations of Entrepreneurship and Economic Development. New York: Routledge.

Hisrich, R.D. \& Peters, M.P. 1998. Entrepreneurship. New York: McGraw-Hill.

Hobsbawm, E. 1969. Industry and Empire from 1750 to the Present Day. New York: Penguin.

Hyder, K. 1999. Green belt bandits. Police Review Magazine. January.

Kalantaridis, C. \& Bika, Z. 2006. In-migrant entrepreneurship in rural England: beyond local embeddedness. Entrepreneurship and Regional Development 18, 109-131.

Kirzner, I. 1979. Competition and Entrepreneurship. Chicago: University of Chicago Press.

Kuratko, D.F. \& Hodgetts, R.M. 1998. Entrepreneurship: Theory, Process, and Practice. Mason, Ohio: South-western/Thomson Learning.

Lowe, P. \& Talbot, H. 2000. Policy for small business support in rural areas: A critical assessment of the proposals for the small business service. Regional Studies 34, 479487.

McElwee, G. \& Atherton, A. 2005. Publication trends and patterns in entrepreneurship. Journal of Small Business and Enterprise Development, 12, 99-103.

McElwee, G. 2006a. The entrepreneurial farmer: A Pandora's box. Rural Enterprise and Management, 2, 23-42.

McElwee, G. 2006b Farmer's as entrepreneurs: developing competitive skills. Journal of Developmental Entrepreneurship, 11, 187-206.

McNally, S. 2001. Farm diversification in England and Wales - what can we learn from the farm business survey. Journal of Rural Studies, 17, 47-257. 
Nodoushani, O. \& Nodoushani, P.A. 2000. Second thoughts On The Entrepreneurial Myth. International Journal of Entrepreneurship and Innovation, 1, 7-13.

North, D. \& Smallbone, D. 2000a. The innovativeness and growth of rural SMEs in the 1990s. Regional Studies,34, 145-157.

North, D. \& Smallbone, D. 2000b. Innovative activity in SMEs and rural economic development: Some evidence from England. European Planning Studies, 8, 87-106.

Palich, L. \& Bagby, D. 1995. Using cognitive theory to explain entrepreneurial risktaking: Challenging conventional wisdom. Journal of Business Venturing, 10, 425438.

Parliamentary Select Committee on the Environment, Food and Rural Affairs (session 2002-2003) Gangmasters. First report.

Rae, D. 2000. Understanding entrepreneurial learning: A question of how? International Journal of Entrepreneurial Behavior and Research 6, 145-149.

Rae, D., \& Carswell, M. 2000. Using a life story approach in researching entrepreneurial learning: The development of a conceptual model and its implications in the design of learning experiences. Education and Training, 42, 220-227.

Rehn, A. \& Taalas, S.:2004. "Znakomstva I Svyazi!” (Acquaintances and Connections) Blat, the Soviet Union, and Mundane Entrepreneurship. Entrepreneurship and Regional Development, 16, 235-250.

Roberts, S. 2002. Key Drivers of Economic Development and Innovation in Rural Areas. London: Routledge.

Say, J.B. 1803. A Treatise on Political Economy, or the Production, Distribution and Consumption of Wealth http://socserv.mcmaster.ca/econ/ugcm/3l13/say/treatise.pdf (Accessed 19/03/2006).

Schindehutte, M., Morris, M. \& Allen, J. 2005. Homosexuality and entrepreneurship: Implications of gay identity for the venture-creation experience. International Journal of Entrepreneurship and Innovation, 6, 27-40.

Schramm, C. 2006. The high price of low ethics: How corruption imperils entrepreneurship and American democracy. Journal of Markets and Morality, 9, 277291.

Schumpeter, J. 1942. Capitalism, Socialism and Democracy. Routledge: London. 
Scott, S. \& Venkataraman, S. 2000. The promise of entrepreneurship as a field of research. Academy of Management Review, 25, 217-226.

Smith, R. \& Christou, M. 2009. Extracting value from their environment: some observations on pimping and prostitution as entrepreneurship. Journal of Small Business and Entrepreneurship, 22, 69-84.

Smith, R. 2004. Rural rogues: a case story on the "smokies" trade' International Journal of Entrepreneurial Behaviour \& Research 10, 277-294.

Smith, R. 2007. Editorial. International Journal of Entrepreneurship and Innovation 8, 245-250.

Stevenson, H.H. \& Jarillo, J.C. 1990. A paradigm of entrepreneurship: entrepreneurial management. Strategic Management Journal, 11, 17-27.

Storr, V.\& Butkevich, B. 2007. Subalternity and entrepreneurship: Tales of marginalised but enterprising characters, oppressive settings and haunting plots. International Journal of Entrepreneurship and Innovation, 8, 251-260.

Timmons, J.A. 1999 ( $5^{\text {th }}$ edition). New Venture Creation; Entrepreneurship for the $21^{\text {st }}$ Century. Boston: McGraw Hill.

Warren, L. 2007. The establishment strikes back? The life and times of Takafumi Horie. International Journal of Entrepreneurship and Innovation, 8, 261-270.

Wempe, J. 2005. Ethical entrepreneurship and fair trade. Journal of Business Ethics, 60, 211-220.

Williams, C.C. 2009. Beyond legitimate entrepreneurship: the prevalence of off-thebooks entrepreneurs in Ukraine. The Journal of Small Business and Entrepreneurship, 22, 55-68.

Williams, C.C. 2008. Beyond necessity- versus opportunity-driven entrepreneurship: a study of informal entrepreneurs in England, Russia and Ukraine' International Journal of Entrepreneurship and Innovation, 9, 16-24.

Williams, C.C. 2006. The Hidden Enterprise Culture: Entrepreneurship in the Underground Economy. Cheltenham, England: Edward Elgar. 